vol. 23, $n^{\circ} 2$ | 2019

Varia

\title{
Pieter Spierenburg as a Mentor and Inspirer
}

\section{Manon van der Heijden}

\section{(2) OpenEdition \\ Journals}

Electronic version

URL: https://journals.openedition.org/chs/2566

DOI: $10.4000 /$ chs. 2566

ISSN: 1663-4837

\section{Publisher}

Librairie Droz

\section{Printed version}

Date of publication: 18 December 2019

Number of pages: 103-105

ISSN: 1422-0857

\section{Electronic reference}

Manon van der Heijden, "Pieter Spierenburg as a Mentor and Inspirer", Crime, Histoire \& Sociétés /

Crime, History \& Societies [Online], vol. 23, n² | 2019, Online since 06 May 2020, connection on 03 April 2022. URL: http://journals.openedition.org/chs/2566 ; DOI: https://doi.org/10.4000/chs.2566

This text was automatically generated on 3 April 2022.

(C) Droz 


\title{
Pieter Spierenburg as a Mentor and Inspirer
}

\author{
Manon van der Heijden
}

1 Pieter Spierenburg was my teacher, promotor and mentor in the academic world. I got to know him in 1987 as a first year student History at the Erasmus University of Rotterdam. He was an assistant professor or associate professor at that time, and he gave the first-year lectures on his book De verbroken betovering. Mentaliteitsgeschiedenis van preïndustrieel Europa (The broken enchantment. The history of mentality in pre-industrial Europe). Like many other students I chose his classes in the following years because of the exciting and stimulating subjects. He focused on, what he called "the pre-industrial period", the period before 1800 . He had a keen eye for exciting subjects that attracted students: murder and manslaughter, corporal punishment, executions and torture, witches and sorcery, insanity, love and sexuality. In his book on the history of mentality, he discussed all these subjects, and he offered explanations for long-term developments. I read the book for the first time as first-year student, but I also referred to it often in subsequent years.

2 His classes and research were innovative. Not only because of the subjects covered, but also because of Pieter's approaches to these topics. At that time most historians focused strongly on political history and the lives and ideas of the elites, and when it came to history of mentality, most historians focused on the ideas of intellectuals. He belonged to a new school that was concerned with the history of the daily lives of people who belonged to the lower reaches of society, the poor, criminals and those living on the margins. He looked at ordinary people who had faced hardship, who had had few options available to them, and who had ended up in court because of poverty, violence, bad luck, and stupidity. Or worse: they ended up on the scaffold.

3 For his research, he used unusual sources, which until then had been rarely used by historians. Notably, sentences of judges, confessions of suspects, and statements of witnesses which he found in the archives of houses of correction, prisons and other institutions that exercised social control over the lives of ordinary people. His work was exceptional for another reason: he combined labour-intensive research into 
primary sources with a theoretical approach. His work was empirically as well as theoretically strong. Anyone who knew him could not ignore it: Norbert Elias' theory of a "civilising process" was an inspiration and guide to Pieter's work. His theoretical approach was quite unusual among historians at the time. In his classes, at conferences, in his publications, and even in the coffee room at the university, Pieter defended Elias by fire and by sword. In Crime, History \& Societies he had a fierce polemic debate with German colleague Gerd Schwerhoff on the use and value of the Elias' theory.

But perhaps the most extraordinary thing about Pieter's work was its international scope. From the 1970s he wrote articles for international peer refereed journals, he published his work in English, and his books were published by international renowned academic publishers. He even wrote his dissertation in English, and had it published by Cambridge University Press in 1984 under the title The Spectacle of Suffering. Pieter became one of the most productive and most publishing historians, and his work was characterized by an unprecedented quantity and quality that stemmed from his drive and enormous work ethic.

It was only when I became a PhD-student and researcher myself that I really appreciated just how important Pieter was as an academic and how significant his reputation was internationally. As I began to attend international conferences, it became apparent that Pieter was pivotal in the formation of international research networks on the history criminality. He was one of the foremost in the field, and his books were standard works. I also discovered how much appreciation and admiration there was for his research, how high-quality his publications were, and how much his theoretical approach and empirical research were an example to others. For any historian or scholar writing about violence in the past Pieter's work has become a point of reference. It is almost impossible to write about long term trends in crime or violence without mentioning Pieter's work. When Steven Pinker was interviewed in the Netherlands for his book The Better Angels of Our Nature he cited Pieter on the differences in violence between the north and south of the United States. Pieter's indisputable position in the field was proven once again at the European Social Science Conference in Vienna in 2014, where a special session was dedicated to his retirement. And it was proven again when Pieter passed away on the 21 March of 2019. The Dutch newspapers memorized him as a great life artist and internationally renowned historical criminologist.

6 It is puzzling, and also a touch bitter, that he did not receive the appreciation that he deserved in The Netherlands. Indeed, it was said that Pieter was not an easy man and that he was sometimes difficult to deal with. He could be self-righteous, sometimes tactless, and stubborn if he had painted himself into a corner, and he had fixed habits that he was very reluctant to deviate from. A conference that started at 9:00? Without sense of decorum, he came in at ten o'clock during the presentation of a colleague. At a conference that we had organized on Crime and Gender in 2017, Pieter also found the start time too early. So, he came in too late, during a presentation, moved next to me and he grumbled at the audience and me in particular: "Hmm, how could I have known that it would start so early?"

7 But he was also generous and loyal. No matter how great his admiration for Elias, he gave me as a PhD student complete freedom in making my own academic choices. He also introduced me to the criminal justice history network, prompted me to present papers at conferences, and he gave me the chance to publish in volumes on crime and 
social control. That loyalty was true for others, too. When a student assistant was not paid due to an error, he paid the salary out of his own pocket. Despite his fierce polemic with Gerd Schwerhoff, he asked him to contribute to a conference he organized and a subsequent volume on social control. That collegiality characterized them both, because Schwerhoff concluded an article with a word of thanks to Pieter for having been kind enough to correct his English.

8 Where his single-mindedness led, on occasion, to annoyance among Dutch colleagues, Pieter was embraced by international colleagues in the criminal justice network, who accepted all his idiosyncrasies. International colleagues seemed rather to regard his obstinacy, and his sometimes unpolished and transverse behaviour, as charming, funny and authentic. They seemed to see his behaviour as just a typical thing for Pieter, which was part of his sharp mind and his original character. That combination of character traits had indeed resulted in numerous beautiful books and articles, and without his obstinacy there had been no tantalizing theory about the long-term decline in violence.

9 After the announcement of his death, has wife Gisèle received many responses from international colleagues who expressed great appreciation for his work and personality. They referred not only to his incredible contribution to the field, but also to his kindness, generosity, collegiality and friendship. I sincerely hope that he has been aware of this great appreciation.

\section{AUTHOR}

\section{MANON VAN DER HEIJDEN}

Leiden University

M.P.C.van.der.Heijden[at]hum.leidenuniv.nl 